\title{
The Emotional Component of the Personality's Psychological Health in the Area of Interaction of the Educational Environment of Modern Students
}

\section{Емоційна складова психологічного здоров'я особистості у просторі інтеракції освітнього середовища сучасного студентства}

\author{
Antonina Kichuk \\ Ph.D. in Psychology, Assistant Professor, Izmail State Uni- \\ versity of the Humanities, Izmail (Ukraine) \\ ORCID ID: https://orcid.org/0000-0002-2657-661X \\ E-mail: tonya82kichuk@gmail.com
}

\section{Антоніна Кічук}

Кандидат психологічних наук, доцент, Ізмаїльський державний гуманітарний університет, м. Ізмаїл (Україна)

\begin{abstract}
Nowadays in the context of actualization of those personal properties with a characteristic mobilization potential, the article presents the results of analytical work aimed at expanding scientific ideas about the emotional personal characteristics of the psychological health of modern students. Basing on the importance of the emotional and energy resource of a young personality under the current conditions of emotional pressure of socio-economic circumstances and virtual factors of the information environment on the central new formations of this age period, it is proved that emotionality is the "focus of the intersection"
\end{abstract}

Address for correspondence, e-mail: kpnu_lab_ps@ukr.net Copyright: (C) Kichuk Antonina

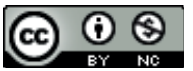

The article is licensed under CC BY-NC 4.0 International

(https://creativecommons.org/licenses/by-nc/4.0/)

(C) Kichuk Antonina

DOI (article): https://doi.org/10.32626/2227-6246.2019-46.219-239 
of all kinds of emotional modalities. The purpose and objectives of the article are proved: to describe some constructive approaches that determine the vectors of psychological substantiated problem field exactly of the features of the emotional component of a young personality's psychological health (psychological health of the individual as an element of society; emotional personal features of psychological health on the basis of modern scientific features concerning the functional structure of the human psyche; functions - properties - states processes). The importance of the interactive approach as a theoretical and methodological paradigm being able to explain the vitally creative activity of a young personality in the context of levels (potential, actual, limiting) and the possibility of full consideration of the dominant of interaction in view of the available emotional features of his (her) psychological health are emphasized. The effectiveness of native and foreign psychological practices, which, based on interactive methods, allow to take into account the emotional spectrum of cognitive experiences of students - subjects of the educational process of modern higher education - has been ascertained. The conclusion is made that, in view of the identified requirements by psychologists, the validity is proved to consider the phenomenology of security as the part of psychological science; the significance of the psychological dimension of the educational environment of modern students is actualized. After all, this is a factor that is directly related with the phenomenon acquiring a positive trend of development - "the modern risk society».

Key words: psychological health, emotional personality-based characteristics of psychological health, youth, interactions, safe educational environment.

\section{Вступ}

На сьогодні вітчизняний соціум диктує необхідність здатності майбутніх фахівців до особистісно-професійної самореалізації в умовах стрімких змін. Це відчутно позначається на тих особистісних властивостях, які в мінливих життєвих ситуаціях віддзеркалюють мобілізаційний потенціал особистості. 3-поміж таких властивостей чільне місце посідає здоров'я майбутнього фахівця у психологічній сфері. 3 урахуванням тиску всієї сукупності соціальних чинників саме на емоційно-енергетичний ресурс особистості, загострюється проблематика емоційно-особистісних особливостей психоло(C) Kichuk Antonina

DOI (article): https://doi.org/10.32626/2227-6246.2019-46.219-239 
DOI: https://doi.org/10.32626/2227-6246.2019-46

2019. Випуск 46

гічного здоров'я сучасного студентства, що значно посилюється через своєрідність особистості саме юнацького віку; до того ж, загострюється не лише набуттям нею професійної ідентичності й остаточною визначеністю в життєвій філософiï, а й вибором сімейних цінностей.

На думку як українських (Массанов \& Іщенко, 2019), так і зарубіжних (Yun, Shim \& Jeong, 2019) дослідників, сучасній молоді властива активна зануреність у віртуальний світ, що утворює неконтрольований чинник впливу - мережеве співтовариство - на психологічне здоров'я особистості. При цьому емпіричні дослідження проблематики психології віртуальності актуалізують не тільки емоційний компонент їі реального спілкування, а, насамперед, додають цьому спілкуванню ознак штучності специфічними засобами електронних соціальних мереж. Таку тенденцію засвідчують і результати нашого дослідницького пошуку (Дерев'яненко, 2008).

Систематизувавши положення класичної психологічної науки, сучасні науковці (Массанов, 2019: 24) по-новому оцінили положення щодо доречності осмислення в якості «одиниці» формування свідомості особистості й пояснення її поведінки поняття «переживання». Водночас слід урахувати сучасне наукове трактування поняття «переживання», адже науковці схильні трактувати його ширшим за емоції і почуття, оскільки саме переживання не обмежуються афективною сферою особистості, а пов'язані з діяльністю, що їх і спонукає. До того ж, розширенню наукових уявлень про місце переживань у явищі, яким постає психологічне здоров'я, сприяє введення поняття «базисне переживання». Якщо розуміти підвалинами психологічного здоров'я особистості феномен «внутрішній світ» (тобто те, що формує їі абриси про навколишне середовище та власне «Я»), то значний інтерес становить трактування базисних переживань за Н. Тавровецькою (Тавровецька, 2019: 360), а саме: «їх можна визначати як імпліцитні, глобальні, стійкі уявлення про світ і про себе, котрі мають вплив на мислення, емоційні стани і поведінку

(C) Kichuk Antonina

DOI (article): https://doi.org/10.32626/2227-6246.2019-46.219-239 
людини». Доречно додати ще й таке: для особистості юнацького віку базисні переконання слугують тією «внутрішньою опорою», яку вона або спростовує, або зміцнюе впродовж життя; натомість такі базисні переконання зароджуються в дитинстві. Учені стверджують: переживання $є$ відображенням того, що віддзеркалює накопичені особистістю узагальнення (досвід) і систему відносин (Прохоров, 2001). Відтак, логічним виглядає розуміння, що саме якість емоційних переживань особистості репрезентують знак і модальність, тобто те, що домінуе в емоціях. Емоційність становить, за влучним висловом психологів, «фокус перетину» всього різновиду емоційних модальностей; відтворюючи індивідуальне «емоційне прочитання» певної емоціогенної ситуації, саме емоційність, як особистісна риса, впливає на формування усіх рівнів розвитку особистості (Саннікова, 2018: 173).

Отже, дбаючи про збереження здоров'я особистості у психологічній сфері, цілковито вмотивовано зосередити дослідницьку увагу саме на емоційних складових.

Мета статті - здійснити аналіз стану розробки в сучасних психологічних дослідженнях проблеми емоційно-особистісних особливостей психологічного здоров'я студентської молоді.

\section{Завдання статті}

1. Провести аналіз теоретико-емпіричних досліджень проблематики психологічного здоров'я особистості юнацького віку, де контекстними постають емоційні особливості.

2. З'ясувати емоційно-особистісні особливості психологічного здоров'я студентів, що домінують в інтерактивному освітньому середовищі закладу вищої освіти.

\section{Методи та методики дослідження}

У дослідженні використано методи теоретичного аналізу напрацювань дослідників, що дало змогу з'ясувати підходи сучасних науковців і практиків до осмислення емоційних (C) Kichuk Antonina

DOI (article): https://doi.org/10.32626/2227-6246.2019-46.219-239 
DOI: https://doi.org/10.32626/2227-6246.2019-46

особливостей психологічного здоров'я особистості юнацького віку.

\section{Результати та дискусії}

Наукове пізнання емоційно особистісних особливостей психологічного здоров'я лежить у площині психологічних уявлень учених дотично розуміння наукового статусу понять «процеси», «стани», «властивості» у психологічній структурі особистості. Ми виходили з того, що особистість як важливий елемент системи соціуму виконує в ній певні функції (соціальні ролі). За параметром «часовий вимір» уважаються більш довготривалими саме функції. У процесі життєдіяльності певна ситуація актуалізує відповідну особистісну властивість, а психологічний стан виступає своєрідним тлом перебігу психологічних процесів. Рівень «функції» контролюється свідомістю особистості, адже йдеться про особистісний смисл, що вкладається в певну функцію і ставлення особистості до неї. Отже, на тлі загального уявлення про функціональну структуру психіки людини видається за можливе сконцентрувати дослідницьку увагу на властивості, якою постає психологічне здоров'я особистості, а також деталізувати емоційно-особистісні його особливості у студентів на підгрунті загальних уявлень, які склалися у науковців, щодо функціональної структури психіки людини (Прохоров, 2011). Ідеться про те, що функціональні структури реалізуються у великому просторово-часовому континуумі, виступаючи динамічним відображенням психологічної структури особистості (функції - властивості - стани - процеси).

Зазначене дає підстави окреслити межі психічного та психологічного здоров'я особистості, опанувати взаємозв'язок, взаємозалежність і взаємозумовленість означених явищ. Адже сучасні психологи вважають найущільненішим зв'язок між такими порівняно близькими психологічними явищами, якими й $\epsilon$ «психічне» $\mathrm{i}$ «психологічне» здоров'я особливості. Оскільки психічне здоров'я - це функціональне явище, де

(C) Kichuk Antonina

DOI (article): https://doi.org/10.32626/2227-6246.2019-46.219-239 
завжди впливовим є контекст, то вчені (Виготський \& Лурія, 1993) стверджують, що норми психічного здоров'я встановити неможливо. Водночас існує думка (Акопян, 2012: 13) відносно того, що психічне здоров'я особистості достатньою мірою залежить від її соціальної інтеграції. Щодо психологічного здоров'я, то науковцями здебільшого визнані такі його маркери: йдеться, по-перше, про особливий «стан відкритості до досвіду»; по-друге, про ущільнений контакт із внутрішнім світом і зовнішньою реальністю; по-третє, про конструктивність самовираження особистості в життєвих ситуаціях. У цьому відношенні ми поділяємо дослідницьку позицію, за якою, з одного боку, психічне здоров'я особистості є важливою передумовою її здоров'я у психологічній сфері, а 3 іншого - доречно осмислювати феноменологію психологічного здоров'я через призму атрибутів такого явища, яким постає «розвиток».

Видається це особливо конструктивним, якщо водночас спиратися на фундаментальний доробок Г. Крайга і Д. Бокула (Крайг \& Бокула, 2006). Так, у науковому дискурсі розвиток трактується як «регулярні та відносно стійкі зміни» в організмі, мисленнєвих процесах, емоціях, формах соціальної взаємодії тощо; до того ж, конструктивність означеного підходу науковцями оцінена ще й за параметром «одночасного утримання» у полі зору і процесів становлення, формування та перетворення (що, як відомо, є не лише самостійними, а ще й самодостатніми). Як внутрішній світ особистості психіка репрезентує всю сукупність її структурних складових (властивості, стани, процеси).

Отож, послуговуючись терміном «психологічне здоров’я», тим самим i наголошується на єдності як тілесного, так i психічного, на «необхідності й того, й іншого для повноцінного функціонування і розвитку»; провідною ж функцією психологічного здоров'я визнаємо саме підтримку балансу «між людиною і довколишнім у тих ситуаціях, які потребують мобілізації ї̈ потенціалу як особистості» (Шапошникова, 2007: 29).

(C) Kichuk Antonina

DOI (article): https://doi.org/10.32626/2227-6246.2019-46.219-239 
Водночас уважаємо суттєвими зауваги про те, що психологічне здоров'я є свідченням не відсутності хвороби, а віддзеркаленням повного психологічного благополуччя (Кузнєцов \& Зотова, 2017: 3). Зазначене набуває виняткової ваги з огляду на своєрідність особистості саме студента, адже цей віковий період здебільшого збігається з юнацтвом, коли «ресурси здаються невичерпними, а оптимізм стосовно власного здоров'я переважає над турботою про нього» (Царькова, 2014: 128). Це підтверджується результатами проведеного емпіричного дослідження (респондентами якого були студенти Харківського національного університету ім. Г. Сковороди), що грунтувалося на психодіагностувальному інструментарії, де базового значення набула методика вивчення рівня здоров'я особистості в різних сферах, валідність якої загальновизнана науковцями (Кузнєцов \& Зотова, 2017: 102-103). До того ж, як переконує і практика, і проведені емпіричні дослідження, саме студентський вік збігається зі складним періодом особистісно-професійного самовизначення, коли ще бракує здатності до емоційно-вольової саморегуляції. А остання, як відомо, має засновничими принципи релаксації, візуалізації та самонавіювання. Отож, ідеться про здатність студента враховувати власні внутрішні ресурси задля вироблення ефективної стратегії подолання труднощів, зниження рівня тривоги, виключення негативних установок.

Якщо при цьому розуміти своєрідність i, водночас, виняткову вагу в означеному балансі емоційного компонента, то, вочевидь, усе ж можна погодитися з визнанням важливим набуття особистістю гармонійності не в сенсі «стану», а в смислі «процесу». Саме динаміка останнього пов'язана 3 усіма атрибутами філософсько-психологічного явища, яким виступає «духовність». Класична психологія визнає вагу духовної складової усіх «пелюстків» здоров'я особистості, адже «духовність - це не просто її характеристика, а провідна особливість. Духовне не просто характеризує особистість разом із тілесним і психічними аспектами, які властиві й твари-

(C) Kichuk Antonina

DOI (article): https://doi.org/10.32626/2227-6246.2019-46.219-239 
нам, бо це те, що відрізняє її, що дано тільки їй і їй одній» (Маслоу, 2001). Відтак, дбаючи про повноту здоров'я у психологічній сфері, варто розуміти вагу повноти їі духовного розвитку. Це дає змогу пояснити, чому небезпідставно I. Дубровіна, заангажовуючи поняття «психологічне здоров'я», описує його як прояв «сили Я» $\mathrm{i}$ «духовного здоров'я».

Отже, психологічне здоров'я особистості сучасного студента постає в якості такої динамічної властивості, що детермінує, з одного боку, його соціальні ролі, а з іншого - віддзеркалює особистісну ресурсність, задіяність і змобілізованість якої є визначальною щодо вияву «Я-концепції» у мінливих життєвих ситуаціях. Ось чому, на наш погляд, мають рацію ті науковці, які розглядають психологічне здоров'я особистості у тісному взаємозв'язку з такими явищами, як «розвиток» $\mathrm{i}$ «зміни». У цьому відношенні в психології вже склалася точка зору: «розвиток», на відміну від «змін», передбачає не тільки і не стільки наявність руху, скільки прагнення особистості до певної мети, котра визначає «послідовне накопичення позитивних новоутворень» (Шапошникова, 2007: 28). У цьому ракурсі психологічне здоров'я може бути осмислено в якості важливого аспекту зрілості особистості за параметрами, визначеними класичною психологією, а саме: 1) функціонально автономною поведінкою особистості, що безпосередньо пов'язана з її здатністю до емоційної самореалізації; 2) характер такої поведінки вмотивований усвідомленими процесами (у тому числі процесом збереження частоти і ступеня позитивних емоцій). Принагідно зауважимо, що ще у 1925 р. А. Лазурський визначив, що здорова особистість здатна виявляти уміння регулювати вчинки і поведінку в межах соціальної норми, а Г. Олпорт, склавши у 1937 р. психологічний портрет здорової особистості, виокремив, зокрема, риси, пов'язані з характеристиками ії переживань, емоцій, почуттів (на кшталт - здатність керувати власним емоційним станом і демонструвати емоційну захищеність, спроможність емоційно виявляти власну самооб'єктивність). (c) Kichuk Antonina

DOI (article): https://doi.org/10.32626/2227-6246.2019-46.219-239 
Освітній процес сучасної вищої школи може бути осмислений як своєрідний мікросоціум, де когнітивні чинники мають різновекторний і різнорівневий вплив на психологічне здоров'я, зокрема, студентства. Навіть існує психологічне обгрунтування взаємозв'язків між безпекою освітнього середовища, психологічним здоров'ям і навчальною успішністю учнівської молоді (Maralov \& Sitarov 2018). При цьому психологи, здебільшого, схильні розуміти безпеку освітнього середовища в контексті чинників ризику. Наприклад, існує думка, що безпека суб'єктів освіти (одними з них і виступає учнівська молодь) вимагає діяльності з формування у них особистої безпеки та безпеки оточуючих. Отже, така діяльність, з одного боку, націлена на визначення, пропедевтику, ослаблення й усунення загроз на рівнях особистості, групи, соціокультурного середовища загалом, а з іншого - реалізується з урахуванням зовнішніх і внутрішніх психологічних чинників (одним із яких є здоров'я особистості у психологічній сфері). При цьому деякі вчені (Кислякова, Шмелєва \& Толтов, 2015) по-новому оцінюють актуальність зауваження А. Маслоу відносно вирішального значення середовища найвагомішого з чинників «самоактуалізації та здоров'я» (Маслоу, 2001: 364). До того ж, учені наполягають на доречності осмислювати конструкт «безпечне освітнє середовище» у якості функціональної системи, котру характеризують певні маркери (на кшталт - «здоров'язбережувальна», «ненасильницька», «розвивальна»), адже вона функціонує в «сучасному суспільстві ризику». Деталізуючи породжений таким суспільством різновид аддикцій (зокрема, учнів старшої школи як суб'єктів освіти і потенційних абітурієнтів закладів вищої освіти), дослідники наводять емпіричні дані про те, що лише 35\% респондентів (вибірку склали 700 осіб) оцінюють свій спосіб життя «здоровим» (Кисляков, Шмелєва \& Толстов, 2015: 49), де одним із параметрів убачається саме здатність керувати власними емоціями.

(C) Kichuk Antonina

DOI (article): https://doi.org/10.32626/2227-6246.2019-46.219-239 
Вищеокреслене й зумовило дещо категоричне судження деяких психологів відносно правомірності розглядати феноменологію безпеки як частину психічної науки.

Слід зробити заувагу, що психологи (Вірна, 2019; Дерев'яненко, 2008; Массанов \& Іщенко, 2019) б'ють на сполох: намагаючись оптимізувати вплив на емоційну сферу особистості юнацького віку, здебільшого поза увагою залишаються висновки класичної психологічної науки, що безпосередньо або опосередковано торкаються саме студентської молоді. Йдеться, по-перше, про те, що саме завдяки емоціям людина перешкоджає тим загрозам, яким вона протистоїть. У цьому сенсі не лише вищі емоції (які здебільшого називають почуттями), а й короткочасні ситуативні переживання (на базі котрих і виникають стійкі емоційні ставлення) пов'язані 3 соціально-психологічним виміром безпеки особистості (Вірна, 2019). По-друге, згідно з визначеною науковцями природою емоцій (Симонов, 1966), де винятковим є значення потягу (мотивації) як цілеспрямованої потреби та виконуваної ролі «акомпанементу» діяльності, а також атрибутивністю емоції стосовно дії особистості, принципово важливо спиратися на науково обгрунтовані шляхи впливу на емоційну сферу (дефіцит інформації; формування інтенсивних потреб; активізація репродуктивних дій особистості у процесі розв’язання «надзавдань»). По-третє, принципової важливості набуває психологічне положення про те, що функція позитивної емоції в життєдіяльності особистості лежить у площині «додаткового стимулювання» (Симонов, 1966: 82). Відтак, визначаючи психологічну стратегію впливу на емоційну сферу студентства, доцільно сфокусувати увагу на питаннях потреб, дій, здібностей. Не менш суттєвим видається розуміння того, що палітра емоційного реагування у кожного різна і за відмінних умов є продуктивною.

Загальновизнаним уважається суто психологічний сенс інтеракції (Г. Балл, О. Власова, В. Семиченко та ін.). Згідно базової ідеї засновника інтеракціоналізму Дж. Г. Міда, (C) Kichuk Antonina

DOI (article): https://doi.org/10.32626/2227-6246.2019-46.219-239 
домінанти міжособистісної взаємодії та спілкування (зокрема, суб’єктів освітньої діяльності) доцільно пов'язувати 3 «взаємоорієнтованими акціями і реакціями». Психологи стверджують, що у такий спосіб дещо по-іншому особистість сприймає себе - залежно від того, як їі сприймають інші. Отож, контекстність інтеракції актуалізує таку особистісну якість, зокрема студента, якою постає його здатність до взаємопристосування, що безпосередньо пов'язано із здоров'ям у психологічній сфері. Вважається, що домінуючі психологічні труднощі студентської молоді у цьому плані здебільшого пов'язані зі станом її психологічного здоров'я у розрізі, насамперед, емоційної, міжособистісної та рольової сфер. Якщо ж розуміти, що саме емоційна сфера віддзеркалює узагальнену реакцію особистості на різні за характером екзогенні й ендогенні сигнали, які надходять з оточуючого середовища $\mathrm{i}$ виявляють оцінне її ставлення, то постає проблемне питання про поглиблення наукових уявлень про емоційні особливості психологічного здоров'я сучасного студентства.

3 огляду на вищезазначене, стає більш розлогим розуміння суто психологічного потенціалу інтеракції і в науковому, і у прикладному значеннях. Адже актуалізується ще й такий аспект окресленої проблеми, як здатність особистості студента актуалізувати й оперувати власними ресурсами задля успішного саморозвитку і саморозкриття у міжособистісній взаємодії та спілкуванні. У цьому плані привертають увагу результати деяких емпіричних досліджень, базою яких були і вітчизняні, і зарубіжні заклади вищої освіти, а респондентами - особи у віці 20-25 років. Установлено, зокрема, що позитивні почуття, які переживаються особистістю у процесі інтерактивної взаємодії та спілкування з іншими, пов'язані з умінням оновлювати власні ресурси, посилюють змістовність взаємин з іншими, сприяючи збереженню та підтримці таких взаємин (Штепа, 2013: 206).

Саморефлексія досвіду запровадження інтерактивних форм в освітній процес вищої школи переконливо засвідчує

(C) Kichuk Antonina

DOI (article): https://doi.org/10.32626/2227-6246.2019-46.219-239 
про значний потенціал інтеракції в аспекті результативності когнітивного і позитивно-активного в емоційному відношенні функціонування підсистеми «викладач вищої школи - студент». Зокрема, при цьому враховувалася впливовість різних типів інтерактивних засобів.

Оскільки йдеться про студентство, то доцільно враховувати, насамперед, емоційний спектр пізнавальних перетворень особистості. Це, за висновками науковців (Гришина \& Косцова, 2016), реалізується у таких емоціях, як-от: прагнення до пізнання, подолання протиріч, почуття краси та величі. У цьому зв'язку нам видається цікавим ще й застосований означеними дослідниками діагностувальний інструментарій, що включає саме інтерактивні методики, котрим властиві інноваційні ознаки.

I це попри те, що, з одного боку, респондентами були студенти, фаховий вибір яких корелює з типом професій «людина - техніка» (де предметною галуззю виступають природні й штучні мови, умовні позначки, формули, символи тощо); з іншого, мова йде не про дослідження конкретної емоційної спрямованості особистості, а про цілісний системокомплекс. Отож, застосовані методики (наприклад, «Базові потреби Едварда Десі», «Емоції та навчання», «Ретроспектива») дали змогу дослідникам дійти висновку про наявний у студентів дисбаланс в емоційній сфері (Гришина \& Косцова, 2016: 256).

Зазначене підтверджує саме необхідність спеціального дослідження емоційного компонента психологічного здоров'я студентської молоді. Так, у контексті раціогуманістичної концепції Г. Балла (Балл, 2014) психологічне здоров'я (як факт, як норма, як цінність) постає мотиватором ii орієнтації впродовж саморуху до виникнення психологічних новоутворень. На наше переконання, ця концепція характеризується значною пояснювальною потужністю щодо механізмів регуляції саме емоційного складника здоров'я особистості у психологічній сфері. Адже, оперуючи поняттями «людина (C) Kichuk Antonina

DOI (article): https://doi.org/10.32626/2227-6246.2019-46.219-239 
як самоорганізована система» й «світ конкретної людини», ідеться про процес розгортання регуляції на загальному і специфічному рівнях як мотиваційного, так і суто емоційного аспектів. Щодо останнього, то на загальному рівні розрізняється декілька сходинок: першу з них «складає» емоційність, другу - співвідношення емоційних і пізнавальних процесів, а на третій сходинці відбувається «включення» емоцій у гностичні процеси свідомості. У цьому ракурсі методологічно вартісною нам видається ідея дослідити взаємозв'язок емоційних особистісних особливостей і показників вияву психологічного здоров'я. У цьому плані віднаходимо методологічні орієнтири, зокрема, у діалогічній концепції М. Бахтіна: у міжсуб'єктних відносинах суб'єкт визначається конкретністю (адже місце людини в реальному житті є незамінним), цілісністю (що синонімічна їі активності), відповідальністю за дії та положення у світі, невичерпністю (відносно якісної динаміки зростання), відкритістю (адже особистість «живе зсередини», натомість «орієнтована назовні»), незалежністю (у сенсі вибору життєвого шляху). Отже, маркери суб’єктності, за М. Бахтіним, сприяють, з одного боку, уточненню базового явища, що лежить в основі здоров'я особистості у психологічній сфері, а з іншого - осмисленню спільного і розбіжного з такими близькими явищами, якими постають «повноцінно функціонуюча особистість» $\mathrm{i}$ «зріла особистість», де важливою гранню $\mathrm{e}$ «чуття фундаментальної емоційної безпеки i прийняття себе» .

Слід зауважити, що з-поміж проведених дослідниками емпіричних досліджень привертають увагу ті з них, що характеризуються результативністю щодо взаємозв'язку між рівнем сформованості у студентів-першокурсників складових емоційного інтелекту та способами їх реагування в емоціогенних (фрустраційних, стресових) ситуаціях (Дерев'яненко, 2008). Зокрема, спираючись на емоційне самопочуття і емоційне реагування (як характеристики емоційної поведінки першокурсників), установлено: 1) емоційне самопочуття (C) Kichuk Antonina 
студентів із високим і середнім рівнями сформованості емоційного інтелекту характеризується нижчим ступенем дискомфорту; до того ж, показник останнього значно підвищується під час першої заліково-екзаменаційної сесії; 2) якщо вважати емоціогенною ситуацією для першокурсників саме емоційно-проблемну ситуацію, яка стимулює активність на рівні суб'єктивного реагування, то виявлено взаємозв'язки між емоційним інтелектом особистості й конструктивністю вибору стратегій подолання (копінг-стратегій) щодо набуття емоційної стабільності.

\section{Висновки}

Психологічне здоров'я особистості юнацького віку становить зону значних психологічних втрат з огляду на самоцінність означеної особистісної властивості та виняткової ваги студентського вікового періоду в особистісно-професійному становленні й доленосне значення для особистості впродовж ЖитТя.

На основі узагальнення теоретико-емпіричних досліджень можна припустити, що попри відсутність загальновизнаної науковцями концепції психологічного здоров'я особистості, вже склались абриси у цьому плані. Визнано, що приріст позитивних ознак здоров'я особистості в психологічній сфері детерміновано, з одного боку, психологічним дозріванням «самої особистості», а з іншого - розвивальним впливом, що забезпечує студентоцентрований освітній процес у закладах вищої освіти.

Аргументованою визнано наукову позицію щодо правомірності вважати процес розвитку особистості розвитком ї̈ почуттів. Якщо виходити з важливості врахування емоційних особистісних особливостей психологічного здоров'я в юнацький віковий період, то доцільно дбати про здатність студентства виявляти культуру власних переживань, а не їх стримання. Адже накопичення невідредагованих емоцій негативно позначається на психологічному здоров'і, посилюю(C) Kichuk Antonina

DOI (article): https://doi.org/10.32626/2227-6246.2019-46.219-239 
чи вірогідність прогнозування дезорганізації діяльності особистості у нестандартних життєвих і суто навчально-професійних ситуаціях.

Із метою розширення наукових уявлень про емоційну детермінацію психологічного здоров'я студентської молоді доцільним є повноцінне врахування природи емоцій, а також наукового статусу понять «функція», «властивість», «стан», «процес», «емоційна ситуація» (фрустаційна, стресова). У результаті аналізу теоретико-методологічних підходів і конструктивних психологічних практик, що віддзеркалюють домінанти впливовості освітнього процесу вищої школи на збереження здоров'я особистості студента у психологічній сфері, доведено своєрідність чинника інтеракції (актуалізація здатності особистості до взаємопристосування; суцільність впливу на емоційну, міжособистісну та рольову сфери; одночасне утримання в полі зору процесів «становлення», «формування» $\mathrm{i}$ «перетворення»; прикладне значення інтеракції в діагностиці емоційного компонента психологічного здоров'я студентства).

Перспективи подальшого наукового пошуку лежать у площині конкретизації базових емоційних ознак, що можуть характеризувати психологічне здоров'я особистості юнацького віку, й експериментального обгрунтування типологій емоційно-особистісних особливостей психологічного здоров'я студентів сучасного закладу вищої освіти.

\section{Література}

Акопян А. Б. Влияние развлекательных учреждений на психическое здоровье личности. Наука і освіта. 2012. № 10. С. 10-14.

Балл Г. А. Системная трактовка культуры и личности в контексте концепции рациогуманизма. Наука і освіта. 2014. № 9/CXXVI. C. $26-31$.

Вірна Ж Ж. П. Безпека особистості: соціально-психологічний та правовий вимір. Виклики та парадокси соціальної взаємодї̈ в постмодерновому світі: лінгвістичні та психологічні аспекти: Матер. I Міжнародної наук.-практ. конф. Луцьк, 2019. С. 112-115.

(C) Kichuk Antonina

DOI (article): https://doi.org/10.32626/2227-6246.2019-46.219-239 
Выготский Л. С., Лурия А. Р. Этюды по истории поведения: Обезьяна. Примитив. Ребёнок. Москва : Педагогика-Пресс, 1993. 224 с.

Гришина А. В., Косцова М. В. Развитие «познавательного» компонента эмоциональной направленности студентов в процессе профессиональной подготовки. Науковий часопис НПУ іл. М. П. Драгоманова. Серія 12: Психологічні науки. Київ, 2016. Вип. 3 (48). C. 253-257.

Дерев'яненко С. Актуалізація емоційного інтелекту в емоціональних умовах. Соціальна психологія. 2008. № 1. С. 96-104.

Кисляков П. А., Шмелева Е. А., Толстов С. Н. Обеспечение социальнопсихологической безопасности субъектов образования. Boпросы психологии. 2015. № 5. С. 46-55.

Кічук А. В. Деякі психологічні аспекти проблеми вибору особистістю стратегій адаптації в умовах «інформаційної цивілізації». Advances of Science: Proceedings of articles of the International Scientific conference. 2018. P. 319-324.

Крайг Грейс, Бокум Дон. Психология развития. 9-е изд. Санкт-Петербург : Питер, 2006. 940 с.

Кузнецов М. А., Зотова Л. Н. ЖЖизнестойкость и образ здоровья у студентов: монография. Харьков, 2017. 398 с.

Маслоу А. Мотивация и личность. Санкт Петербург : Евроазия, 2001. $430 \mathrm{c}$.

Массанов А. В., Іщенко К. О. Зв’язок емоційного інтелекту і зануреності особистості в інтернет-середовищі. Актуальні проблели практичної психологї: Зб. наук. праць Міжнар. наук.-практ. Інтернет-конференції. Одеса, 2019. С. 24-28.

Прохоров А. О. Саморегуляция психических состояний в учебной и педагогической деятельности. Вопросы психологии. 2001. № 4. C. $112-116$.

Саннікова О. П. Континуально-ієрархічна модель особистості. Психологія і суспільство. 2018. № 3-4 (73-74). С. 166-177.

Симонов П. В. Что такое эмоция? Москва : Наука, 1966. 96 с.

Тавровецька Н. Емпіричне дослідження базисних переконань особистості в контексті подолання життєвих криз. Проблели сучасної психологіі: Збірник наукових праць Кал'янець-Подільського національного університету ілені Івана Огієнка, Інституту психологї̈ іл. Г. С. Костюка АПН України / за ред. С. Д. Максименка, Л. А. Онуфрієвої. Кам'янець Подільський : Аксіома, 2016. № 45. C. $358-380$.

Шапошникова М. П. Психологічне здоров'я суб'єктів освітнього процесу професійної школи. Науковий вісник НПУ іл. К. Д. Ушинського. Одеса, 2007. № 9-10. С. 26-32.

(C) Kichuk Antonina

DOI (article): https://doi.org/10.32626/2227-6246.2019-46.219-239 
Штепа О. С. Особливості психологічної ресурсності осіб 20-25 років 3 різним статусом ідентичності. Наука і освіта. 2013. № 7. С. 204208.

Царькова О. В. Психологічні аспекти збереження психічного здоров'я студентської молоді. Наука і освіта. 2014. № 6. С. 128-133.

Maralov, V. G., \& Sitarov, V. A. (2018). Irritability to people: Typology and mechanisms. Integration of Education, 22, 3, 493-507.

Yun, J.-Y., Shim, G., \& Jeong, B. (2019). Verbal Abuse Related to SelfEsteem Damage and Unjust Blame Harms Mental Health and Social Interaction in College Population. Scientific Reports, 9 (1), 5655.

\section{References}

Akopian, A.B. (2012). Vliianiie razvlekatelnykh uchrezhdeniy na psikhicheskoie zdorovie lichnosti [The impact of entertainment on mental health]. Nauka i osvita - Science and education, 10, 10-14 [in Russian].

Ball, G.A. (2014). Sistemnaia traktovka kultury i lichnosti v kontekste kontseptsii ratsiogumanizma [A systematic interpretation of culture and personality in the context of the concept of ratiohumanism]. Nauka н оsvнta - Science and education, 9, 26-31 [in Russian].

Virna, Zh. P. (2019). Bezpeka osobystosti: socialno-psykholohichnyi ta pravovyi vymir [Personal security: socio-psychological and legal dimension]. Vyklyky ta paradoksy sotsialnoi vzaiemodii v postmodernovomu sviti: lingvistychni ta psykholohichni aspekty - Challenges and paradoxes of social interaction in the postmodern world: linguistic and psychological aspects: Proceedings of the I International Scientific and Practical Conference, Lutsk, (pp. 112-115) [in Ukrainian].

Vygotskii, L.S., \& Luriia A.R. (1993). Etiudy po istorii povedeniia: Obeziana. Primitiv. Rebionok [Studies in the history of behavior: A monkey. A primitive. A child]. Moskva: Pedagogika-Press [in Russian].

Grishina, A. V., \& Kostsova, M. V. (2006). Razvitie «poznavatelnogo» komponenta emotsionalnoi napravlenosti studentov $\mathrm{v}$ protsesse professionalnoi podgotovki [The development of the «cognitive» component of students' emotional orientation during vocational training]. Naukovyi chasopys NPU im. M. Drahomanova - International Standard Serial Number of NPU named after M. Drahomanov. Series 12: Psychological Science, 3 (48), 253-257. Kyiv [in Russian].

Derevianenko, S. (2008). Aktualizatsiia emotsiinoho intelektu v emotsionalnykh umovakh [Updating emotional intelligence in emotional conditions]. Sotsialna psykholohiia - Social Psychology, 1, 96-104 [in Ukrainian].

(C) Kichuk Antonina

DOI (article): https://doi.org/10.32626/2227-6246.2019-46.219-239 
DOI: https://doi.org/10.32626/2227-6246.2019-46

Kysliakov, P. A., Shmeleva, E. A., \& Tolstov, S. N. (2015). Obespechenie sotsialno-psikhologicheskoi bezopasnosti subiektov obrazovaniia [Ensuring the social and psychological safety of subjects of education]. Voprosy psikhologii - Psychology questions, 5, 46-55 [in Ukrainian].

Kichuk, A. V. (2018). Deiaki psykhologichni aspekty problemy vyboru osobystistiu stratehiy adaptatsii v umovakh «informatsiynoi tsyvilizatsii» [Some Psychological Aspects of the Personality's Choice of Adaptation Strategies in the Conditions of «Information Civilization»]. Advances of Science: Proccedings of articles of the International Scientific conference, (pp. 319-324) [in Ukrainian].

Craig Grace, \& Baucum Don (2006). Psikhologiia razvitiia [Developmental psychology], Saint Pitersburg: Piter [in Russian].

Kuznetsov, M.A., \& Zotova, L.N. (2017). Zhiznestoikost i obraz zdorovia $u$ studentov [Vitality and the way of health in students]. Kharkov [in Russian].

Maslow, A. (2001). Motivatsiia $i$ lichnost [Motivation and personality]. Saint Pitersburg: Yevroaziia [in Russian].

Massanov, A. V., \& Ishchenko, K. O. (2019). Zviazok emotsiynoho intelektu i zanurenosti osobystosti $\mathrm{v}$ internet seredovyshchi [The connection between emotional intelligence and the submerged personality of the Internet]. Aktualni problemy praktychnoi psykholohii - Actual problems of practical psychology: Collection of research papers of International Scintific and Practical Internet-Conference, (pp. 24-28). Odesa [in Ukrainian].

Prokhorov, A. O. (2001). Samoreguliatsiia psikhicheskikh sostoianii v uchebnoi i pedagogicheskoi deiatelnosti [Self-regulation of mental states in educational and pedagogical activities]. Vorosy psikhologiiPsychology questions, 4, 112-116 [in Russian].

Sannikova, O. P. (2018). Kontinualno-iierarkhichna model osobystosti [Continuous hierarchical model of personality]. Psykholohiia i suspilstvo Psychology and society, 3-4 (73-74), 166-177 [in Ukrainian].

Simonov, P. V. (1966). Chto takoie emotsiia? [What is emotion?]. Moskva: Nauka [in Russian].

Tavrovetska, N. (2016). Empirychne doslidzhennia bazysnykh perekonan osobystosti v konteksti podolannia zhyttievykh kryz [An empirical study of basic personality beliefs in the context of overcoming life crises]. Problemy suchasnoyi psykholohii - Problems of modern psychology: Collection of research papers of Kamianets-Podilskyi $\mathrm{Na}$ tional Ivan Ohiienko University, G.S. Kostiuk Institute of Psychology of NAES of Ukraine, 45, 358-380 [in Ukrainian].

Shaposhnikova, M. P. (2007). Psykholohichne zdorovia subiektiv osvitnioho protsesu profesiinoi shkoly [Psychological health of the subjects of

(C) Kichuk Antonina

DOI (article): https://doi.org/10.32626/2227-6246.2019-46.219-239 
the vocational school educational process]. Naukovyi visnyk NPU im. K.D. Ushynskoho - Scientific Bulletin of NPU named after K.D. Ushynsky, 9-10, 26-32. Odesa [in Ukrainian].

Shtepa, O. S. (2013). Osoblyvosti psykholohichnoi resursnosti osib 20-25 rokiv z riznym statusom identychnosti [Features of psychological resourcefulness of persons of 20-25 years with different status of identity]. Nauka i osvita - Science and education, 7, 204-208 [in Ukrainian].

Tsarkova, O.V. (2014). Psykholohichni aspekty zberezhennia psykhichnoho zdorovia studentskoi molodi [Psychological aspects of preserving mental health of student youth]. Nauka i osvita - Science and education, 6, 128-133 [in Ukrainian].

Maralov, V.G., \& Sitarov, V.A. (2018). Irritability to people: Typology and mechanisms. Integration of Education, 22, 3, 493-507.

Yun, J-Y, Shim, G, \& Jeong, B. (2019). Verbal Abuse Related to SelfEsteem Damage and Unjust Blame Harms Mental Health and Social Interaction in College Population. Scientific Reports, 9(1), 5655.

\section{Кічук Антоніна. Емоційна складова психологічного здоров'я особистос- ті у просторі інтеракції освітнього середовища сучасного студент- cmea}

\section{АНОТАЦІЯ}

У контексті актуалізації в сучасних умовах тих особистісних властивостей, яким притаманний мобілізаційний потенціал, у статті представлено результати аналітичної роботи, спрямованої на розширення наукових уявлень про емоційні особистісні особливості психологічного здоров'я сучасного студентства. Виходячи з ваги саме емочійно-енергетичного ресурсу особистості юнацького віку за сучасних умов емоційного тиску сочіально-економічних і віртуальних чинників інформачійного середовища на центральні новоутворення цього вікового періоду, доведено, що емочійність $\epsilon$ «фокусом перетину» всього різновиду емоційних модальностей. Обгрунтовано мету і завдання статті - описати деякі конструктивні підходи, котрі визначають вектори психологічно обгрунтованого проблемного поля саме особливостей емоційного компонента психологічного здоров'я особистості юнацького віку (психологічне здоров'я особистості як елемент соціуму; емочійні особистісні особливості психологічного здоров'я на підгрунті сучасних наукових уявлень щодо функціональної структури психіки людини; функції - властивості -

(C) Kichuk Antonina

DOI (article): https://doi.org/10.32626/2227-6246.2019-46.219-239 
DOI: https://doi.org/10.32626/2227-6246.2019-46

стани - процеси). Підкреслено важливість інтерактивного підходу як теоретико-методологічної парадигми, спроможної пояснити життетворчу активність особистості юнацького віку в розрізі рівнів (потенційного, актуального, граничного) та можливість повноцінного врахування домінант інтеракції з огляду на наявні емоційні особливості її психологічного здоров'я. Констатовано результативність вітчизняних і зарубіжних психологічних практик, які, базуючись на інтерактивних методиках, дають змогу врахувати емоційний спектр пізнавальних переживань студентів -суб'єктів освітнього процесу сучасної вищої школи. Зроблено висновки про те, що з огляду на встановлені психологами вимоги доведено правомірність розглядати феноменологію безпеки частиною психологічної науки, актуалізовано вагу психологічного виміру освітнього середовища сучасного студентства. Адже це виступає чинником, що безпосередньо пов'язаний із явищем, яке набуває позитивної тенденції розвитку - «сучасним суспільством ризику».

Ключові слова: психологічне здоров'я, емочійні особистісні особливості психологічного здоров'я, юнацький вік, безпечне освітнє середовище.

Кичук Антонина. Эмоциональная составляющая психологического здоровья личности в пространстве интеракции образовательной среды современного студенчества

\section{АННОТАЦИЯ}

В контексте актуализации в современных условиях жизнедеятельности тех личностно-профессиональных характеристик, которые связаны с мобилизационным потенциалом, в статье представлены результаты аналитической работы, направленной на расширение сложившихся научных представлений об эмоциональных особенностях психологического здоровья современного студенчества. Основываясь на всевозрастающем значении именно эмоционально-энергетического ресурса личности в современных условиях эмоционального давления социально-экономических факторов и виртуальных посредников информационной среды на центральные новообразования юношеского периода, установлено, что эмоциональность обретает положение своеобразного "фокуса пересечения» всего разнообразия эмоциональных модальностей; этим обоснованы цели и задачи статьи - описать некоторые конструктивные подходы, которые определяют векторы психологически обоснованного про(C) Kichuk Antonina

DOI (article): https://doi.org/10.32626/2227-6246.2019-46.219-239 
DOI: https://doi.org/10.32626/2227-6246.2019-46 2019. Випуск 46

блемного поля именно эмоционально-личностных особенностей психологического здоровья юношеского возрастного периода (психологическое здоровье как элемент социума; эмоционально-личностные особенности психологического здоровья на основе современных научных представлений о функциональной структуре психики человека; функции - особенности - состояния - процессы). Подчеркнута важность интерактивного подхода как теоретико-методологической парадигмы, способной объяснить жизнетворческую активность личности юношеского периода в ракурсе определенных уровней (потенциального, актуального, граничного) и возможность полноценного учета доминант интеракции с точки зрения на явные эмоциональные особенности ее психологического здоровья. Констатирована результативность отечественных и зарубежных психологических практик, которые, основываясь на интерактивных методиках, позволяют учесть эмоциональный спектр познавательных переживаний студентов - субъектов образовательного процесса современной высшей школы. Сделаны развернутые выводы относительно того, что проведенные психологические исследования усиливают правомерность осмысления феноменологии безопасности и рассматривают ее как часть психологической науки, усиливая значение психологического параметра образовательной среды современного студенчества. Ведь это выступает тем фрактором, который непосредственно связан с явлением, обретающим позитивные тенденции развития - "современным обществом риска».

Ключевые слова: психологическое здоровье, эмочиональные личностные особенности психологического здоровья, юношеский возраст, безопасная образовательная среда.

Original manuscript received August 28, 2019 Revised manuscript accepted September 23, 2019 